\title{
A survey of land for Weligama Coconut Leaf Wilt Disease affected palms outside the declared boundary in the Southern Province
}

\author{
A. D. Nainanayake ${ }^{1^{*}}$, M. D. P. Kumarathunga ${ }^{1}$, P. H. P. R. de Silva ${ }^{1}$ \\ ${ }^{1}$ Plant Physiology Division, Coconut Research Institute, Lunuwila, 61150, Sri Lanka \\ *Corresponding Author : A.D. Nainanayake,Email: athulasl@yahoo.com
}

\begin{abstract}
After the identification of the Weligama Coconut Leaf Wilt Disease (WCLWD) in 2006, a three $\mathrm{km}$ wide boundary zone was declared which stretched from Galle to Tangalle. All suspicious palms recorded within the boundary zone were removed. Gradual removal of affected palms in the core area was also continued. These actions along with many other precautionary steps were taken with the objective to prevent the spread of the disease further beyond the demarcated boundary. After taking continued precautionary measures for more than 7 years, it was timely to find out the presence of any disease affected palms beyond the boundary. Therefore, a sample survey was conducted along a $4 \mathrm{~km}$ wide belt beyond the boundary. Uniform sampling locations were ensured by selecting sample sites on a $1 \mathrm{~km}$ grid drawn on the areal image of the area. Each grid covered an area of $1 \mathrm{~km}^{2}$ (100 ha). Four sampling locations/plots of approximately 1 ha in extent were selected within each grid. All coconut palms within selected plots were examined for morphological symptoms of the WCLWD and necessary information was recorded. The total area covered by the sample survey was about 40,000 ha and the extent closely examined was about 1600 ha, which was approximately $4 \%$ of the total land area covered by the survey.
\end{abstract}

The results revealed that the precautionary measures taken by relevant authorities to prevent the spread of the WCLWD have had a significant effect in containing the disease within the demarcated area. However, some spread of the disease beyond the boundary was detected in a few places within the four-km-belt beyond the boundary. Thus altogether 18 affected palms were identified in 10 plots in Galle and Matara districts. They were in Akmeemana, Imaduwa and Yakkalamulla DSD in Galle district and Kamburupitiya and Mulatiyana DSD in Matara district. Most of those locations were adjacent to the boundary. However, any detection of even a few affected palms outside the boundary in a sample survey indicates the possibility of having such palms elsewhere in the study area. A comprehensive palm to palm survey is needed for precise detection of such palms. Considering the impending threat from the disease, a palm to palm survey at least within a $4 \mathrm{~km}$ belt outside the boundary is suggested to effectively prevent the spread of the disease, despite the cost and the man power required for such an operation.

Key words.: Phytoplasma, Weligama coconut leaf wilt disease, 


\section{INTRODUCTION}

Weligama Coconut Leaf Wilt Disease (WCLWD) was first reported in 2006 in the Weligama Divisional Secretariat Division (DSD) in the Matara district (Everard, 2013). The early detectable foliar symptom of the disease is the loss of the angular shape of leaflets with subsequent flattening of leaf lamina and bending down which is termed leaf flaccidity (Wijesekara and Fernando, 2013). Intense, uneven yellowing of lower and middle whorl fronds is the most striking feature of this disease (Fig. 1). Necrosis or the drying of leaflets starting from the margin or tip of such leaflets can also occur at a later stage.

According to a survey conducted in 2012 , the disease affected area was estimated around $6 \%$ of the total extent under coconut (Everard, 2013). After demarcating the affected area in 2006, a boundary was declared. The transportation of coconut based plant materials from the affected area was restricted. Moreover, all suspicious coconut palms were removed from the $3 \mathrm{~km}$ wide boundary which stretched from Galle to Tangalle via Imaduwa, Akuressa, Kirinda-Puhulwella, Hakmana, Walasmulla and Beliatta (Everard, 2013). Removal of affected palms was carried out in the core area too. The boundary was based on the main road structure (mainly the A17 route) which cuts across the major towns mentioned above. Three kilometer distance on either side of the road i.e. one kilometer distance outside the road and two kilometer distance inside the road was considered as the major boundary zone. Findings of preliminary experiments conducted in the affected area have revealed that the spread of the disease could be effectively controlled by the removal of disease affected
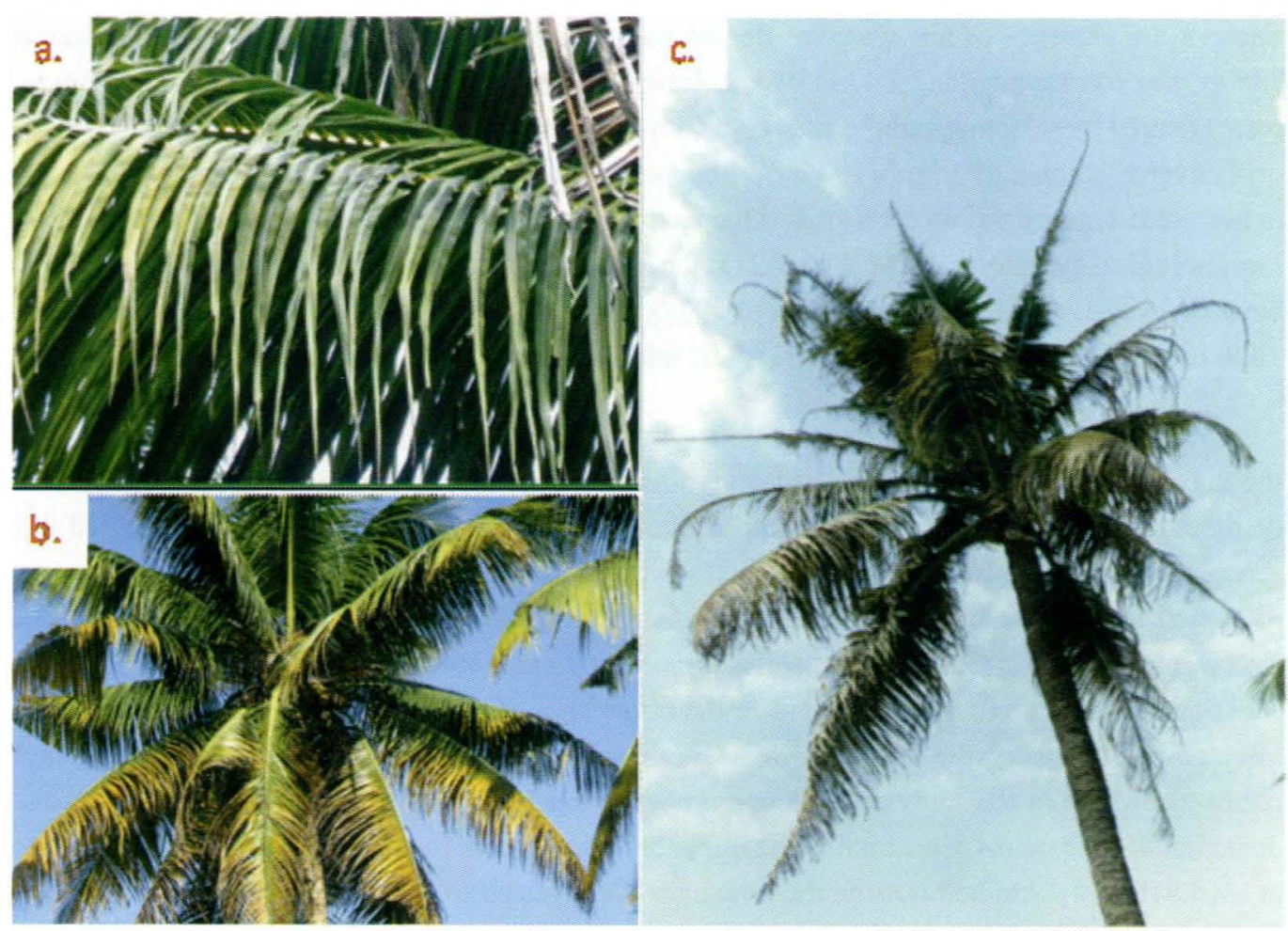

Fig. 1. Common morphological symptoms seen in WCLWD affected palms (a) Leaf flaccidity (b) intense leaf yellowing along with leaf flaccidity (c) Leaf rot affected palm. 
palms, which generally act as an inoculum and spread the disease further (Nainanayake et al., 2013). Accordingly, the palms within the boundary zone were continuously monitored and affected palms were removed. The gradual removal of affected palms in the core area of the disease was also in progress at the same time. As expected, the rate of spread of the disease was significantly arrested within the core area by the measures taken. Thereafter, action was taken to monitor the area beyond the boundary zone, for any sporadic incidences of WCLWD. This was while all precautionary steps needed to prevent the spread of the disease beyond the demarcated boarders were under way. Therefore, surveillance of the area adjacent to boundary, the area mostly vulnerable, was undertaken to detect any incidences.

\section{OBJECTIVES}

The main objective of this surveillance was to detect the presence of any WCLWD incidences within a belt of $4 \mathrm{~km}$, outside the boundary zone from Galle to Tangalle, by conducting a sample survey. The surveillance was conducted to test the effectiveness of the precautionary measures taken by the authorities that comprised of Coconut Research Institute, Coconut Cultivation Board, Department of Agriculture and other relevant officers from Divisional Secretaries in Galle, Matara and Hambantota. Moreover, if any incidences were reported, it was expected to take suitable measures to prevent further spread beyond those locations.

\section{METHODOLOGY}

The area beyond the boundary was divided in to $1 \mathrm{~km}^{2}$ land blocks using a $1 \mathrm{~km}$ grid drawn on areal image of the area (Fig. 2). Uniform sampling along the border was ensured through the selection of sampling locations based on a grid structure.

Four sampling locations of approximately 1ha area were selected from each grid of $1 \mathrm{~km}^{2}$. The area observed per grid was approximately 4 ha and the total area under each grid was 100 ha. Thus, the area examined in the sample survey was approximately $4 \%$ of the total area covered by the survey.

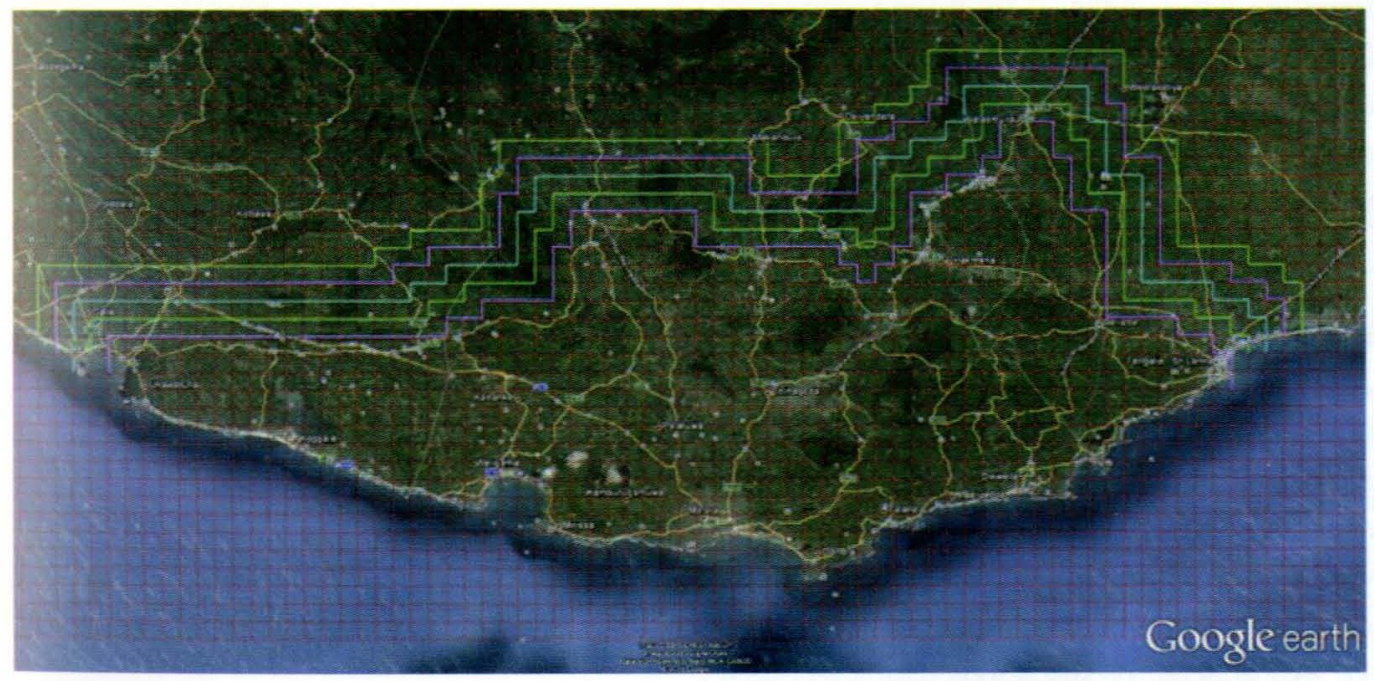

Fig. 2. One kilometer grid laid on the areal image of the area. (The purple line adjacent to the road indicates the first line of grids which were within the $1 \mathrm{~km}$ distance from the road and thus within the boundary zone). 
The presence of WCLWD affected palms within the sampling area was identified using the confirmed morphological symptoms (Wijesekara and Fernando, 2013). Accordingly, palms were examined for the presence of flaccidity or the flattening of the leaf blade with clear bending of the leaflet at the distal end, yellowing of leaflets and the marginal necrosis along the outer edges of leaflets by trained officers. Palms with leaf rot disease which is the rotting of spear leaves of weakened palms due to the action of complex of fungi were also recorded. Accordingly, affected palms and any suspicious palms located within the selected sampling area were counted separately and marked for further actions. Detection was confirmed by the Real Time PCR (RT-PCR) method developed by the Coconut Research Institute for the specific phytoplasma which cause the disease (CRI, 2013).

The first line of the grids adjacent to the boundary road was excluded from the surveillance as it was clearly within the $3 \mathrm{~km}$ wide boundary zone. When some parts of the next grid line also fell on the boundary zone, sampling was conducted from the second grid line onwards for more clarity. Enlarged views of relevant grids were used by monitoring officers for identification of the ground area within a grid.

The ground surveillance commenced in late November, 2014 and continued until the end of April, 2015. A questionnaire was completed at each sampling point, which covered all required information as far as the disease was considered. It included all required information with respect to the disease condition and other general information of a particular land (Fig. 3 ). All affected or suspicious palms recorded were marked for easy identification and further actions.

\section{RESULTS AND DISCUSSION}

Each grid line along the border from Galle to Tangalle consisted of $>100$ grids(covering Galle, Matara and Hambantota districts). Observations were made in more than 400 grids within the $4 \mathrm{~km}$ belt (from Galle to Tangalle) during ground surveillance. Thus the total area covered by this sample survey was about 40,000 ha and the exact area closely observed was slightly less than 1600 ha, when the area under the forest covers was excluded.

\section{Round 1-Area within first $\mathrm{km}$ from the boundary}

According to the initial inspections of sample sites, WCLWD affected or suspicious palms were observed in seven Divisional Secretariat Divisions (DSD) during the first line of grids observed (within $1 \mathrm{~km}$ away from the boundary [ $2 \mathrm{~km}$ distance from the road]) shown in Table 1. Those locations spread along the border covering all three districts. Thus four plots in Akmeemana DSD with eight suspicious palms and two plots in Imaduwa DSD each with one suspicious palm were recorded fromGalle district. Similarly, one plot in Akuressa DSD with two palms, six plotsin Kamburupitiya DSD and one plot in Hakmana DSD with one palm were identified fromMatara district. Although some suspicious palms were reported in Beliatta and Tangalle DSD inHambantota district, re-inspection by experts excluded those palms. Accordingly, only 6 plots with 12 affected palms were identified within one $\mathrm{km}$ outside from the boundary. They were in 2 plots with 6 palms in Akmeemana, 1 plot with 1 palm in ImaduwaDSD in Galle district and 3 plots with 5 palms in Kamburupitiya in Matara district. 
Questionnaire for Surveillance outside the boundary area

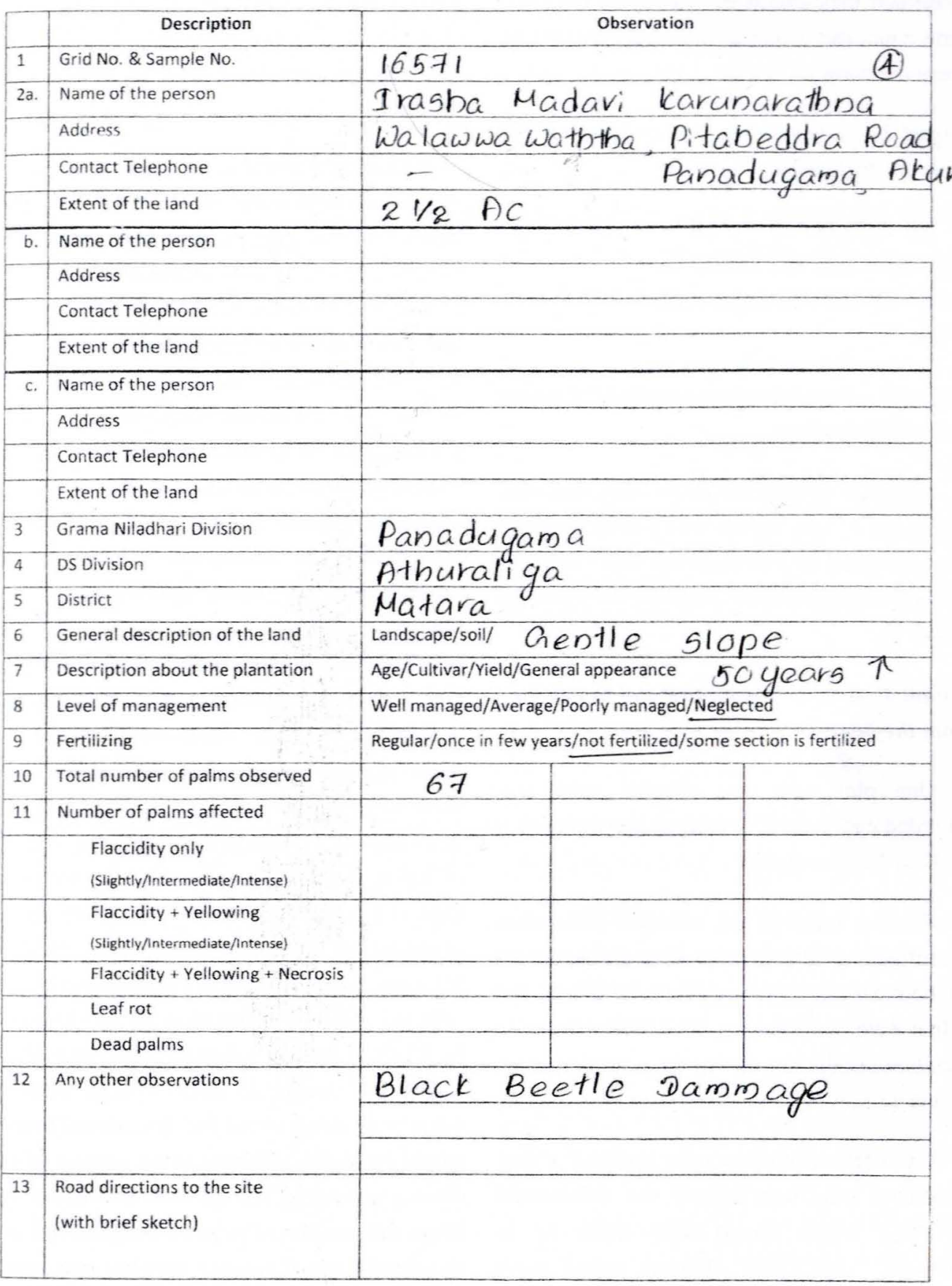

Fig. 3. A completed sample questionnaire 
No suspicious palms were confirmed as WCLWD in Hambantota district. Some of those confirmed locations were within the boundary zone when the distances were calculated with greater accuracy.

\section{Round 2 - Area between first and second $\mathrm{km}$ from the boundary}

No affected or suspicious palms were reported within the second line of grids thus within the second kilometer from the boundary (Table 1).

\section{Round 3-Area between second and third $\mathrm{km}$ from the boundary}

Although no affected palms were identified within the $2^{\text {nd }} \mathrm{km}, 3$ plots with 5 affected palms were recorded in Yakkalamulla DSD in Galle district within the third $\mathrm{km}$ from the boundary (Table 1).

\section{Round 4-Area between third and fourth $\mathrm{km}$ from the boundary}

One plot with one affected palm was recorded within the fourth $\mathrm{km}$ in Kamburupitiya DSD in Matara district.

Thus a total of 18 affected palmswere identified in 10 plots within $4 \mathrm{~km}$ distance from the boundary in Galle and Matara districts. No palms were confirmed as WCLWD affected in Hambantota district during this sample survey (Table 1).

The entire sample survey covered a four kilometer wide belt beyond the demarcated boundary which spread from Galle up to Tangalle. WCLWD affected palms were identified within the four $\mathrm{km}$ belt outside the boundary. All palms confirmed as WCLWD affected (18 palms in 10 plots) have already been removed and relevant compensations have already been paid. A few WCLWD affected palms had been removed in two places (Tangalle and Beliatta) outside the boundary prior to the commencement of this sample survey.

Results revealed that the disease has moved beyond the boundary. But, incidences were highly concentrated to the area adjacent to the boundary, the most vulnerable area. The greater the distance from the boundary, the lesser the number of incidences reported. This indicates that the precautionary steps taken by the relevant authorities based on the strategic plan formulated by the expert committee have been successful up to an appreciable level in managing disease within the identified core area preventing the spread of the disease further. However, these sporadic incidences reported beyond the boundary should be taken as alarms and more vigorous actions should be taken for the identification of affected palms beyond the boundary and rapid removal of them for effective prevention of disease spread. Detecting affected palms beyond the boundary in a sample survey indicates that the possibility of having such palms elsewhere in the study area, if a comprehensive palm to palm survey is conducted. Therefore, paying more attention for a palm to palm survey for identification of affected palms, confirmation of the diagnosis by RT-PCR method followed by the immediate removal of confirmed palms at least within a $4 \mathrm{~km}$ wide belt beyond the demarcated border would be highly effective in prevention of the disease spreading.The quicker the action the lesser the number of palms to be removed and thereby the rest of coconut growing area would be safe. 


\section{CONCLUSION}

The results of the sample survey revealed that precautionary measures taken by relevant authorities to prevent the spreading of the WCLWD have significantly been effective in managingthe disease spread within the demarcated area. However, movement of the disease beyond the demarcated boundary has also been observed,though it is only in 10 plots in 5 DSDs in Galle and Matara districts. Altogether there were 18 affected palms in 10 plots in Galle and Matara districts. They were in Akmeemana, Imaduwa and Yakkalamulla DSD in Galle district and Kamburupitiya and Mulatiyana DSD in Matara district. These locations were much closer to the boundary and thus can be considered them as in the highly vulnerable area. Nevertheless, the detection of affected palms in a sample survey indicates the possibility of having such palms elsewhere in the area monitored, which may be detected only in a comprehensive palm to palm survey. Therefore, the looming threat should be addressed appropriately and immediately, although the number of affected palms observed in the sample survey was relatively small. Hence, conducting a palm to palm survey at least within a $4 \mathrm{~km}$ belt outside the boundary would be highly worthwhile and prudent in managing the spread of the disease effectively, though it requiressignificant cost and the man power for such an operation.

\section{ACKNOWLEDGEMENT}

The assistance extended by Dr. H T R Wijesekara, Head, Crop Protection Division of the Coconut Research Institute during the survey work is highly appreciated. The team of field officers who were attached to the WCLWD Research Centre at Matara was greatly acknowledged for the support extended during field survey works conducted in Galle, Matara and Hambantota districts.

\section{REFERENCES}

Coconut Research Institute. (2013). Research and development highlights, Crop Protection, pp. 31-33, Annual Report 2013, Coconut Research Institute, Lunuwila, Sri Lanka.

Everard, J. M. D. T. (2013). Integrated management of Weligama coconut leaf wilt disease program in Sri Lanka: Strategies, implementation and challenges In: Weligama Coconut Leaf Wilt Disease Six years after (Eds. H. P. M. Gunasena, H. A. J. Gunathilake, L. C. P. Fernando, J. M. D. T. Everard and P. A. H. N. Appuhamy)pp. 13-17, Coconut Research Institute, Sri Lanka.

Nainanayake, A. D, Wijesekara, H. T. R., and Gunathilake, J. (2013). Disease spreading pattern - GIS mapping In: Weligama Coconut Leaf Wilt Disease Six years after (Eds. H. P. M. Gunasena, H. A. J. Gunathilake, L. C. P. Fernando, J. M. D. T. Everard and P. A. H. N. Appuhamy)pp. 48-52, Coconut Research Institute, Sri Lanka.

Wijesekara, H. T. R., and Fernando, L. C. P. (2013). Symptoms and etiology of weligama coconut leaf wilt disease In: Weligama Coconut Leaf Wilt Disease Six years after (Eds. H. P. M. Gunasena, H. A. J. Gunathilake, L. C. P. Fernando, J. M. D. T. Everard and P. A. H. N. Appuhamy)pp. 18-25, Coconut Research Institute, Sri Lanka. 
Table 1. Incidences recorded in Divisional Secretariat Divisions (DSD) in Galle, Matara and Hambantota districts in the Southern Province at different distances beyond the boundary zone.

\begin{tabular}{|c|c|c|c|c|c|c|c|c|c|c|c|c|c|c|c|c|c|}
\hline \multirow[t]{3}{*}{ District } & \multirow[t]{3}{*}{ DSD } & \multicolumn{4}{|c|}{$1 \mathrm{~km}$} & \multicolumn{4}{|c|}{$2 \mathrm{~km}$} & \multicolumn{4}{|c|}{$3 \mathrm{~km}$} & \multicolumn{4}{|c|}{$4 \mathrm{~km}$} \\
\hline & & \multicolumn{2}{|c|}{ Initial } & \multicolumn{2}{|c|}{ Confirmed } & \multicolumn{2}{|c|}{ Initial } & \multicolumn{2}{|c|}{ Confirmed } & \multicolumn{2}{|c|}{ Initial } & \multicolumn{2}{|c|}{ Confirmed } & \multicolumn{2}{|c|}{ Initial } & \multicolumn{2}{|c|}{ Confirmed } \\
\hline & & plots & palms & plots & palms & plots & palms & plots & palms & plots & palms & plots & palms & plots & palms & plots & palms \\
\hline \multirow[t]{5}{*}{ Galle } & Kadawathsathara & & & & & & & & & & & & & & & & \\
\hline & Akmeemana & 4 & 8 & 2 & 6 & & & & & & & & & & & & \\
\hline & Imaduwa & 2 & 2 & 1 & 1 & & & & & & & & & & & & \\
\hline & Yakkalamulla & & & & & & & & & 5 & 7 & 3 & 5 & & & & \\
\hline & BopePoddala & & & & & & & & & & & & & & & & \\
\hline \multirow[t]{7}{*}{ Matara } & Akuressa & 1 & 1 & - & - & & & & & & & & & & & & \\
\hline & Welipitiya & & & & & & & & & & & & & & & & \\
\hline & Athuraliya & & & & & & & & & & & & & & & & \\
\hline & Mulatiyana & & & & & & & & & & & & & 1 & 1 & 1 & 1 \\
\hline & Kamburupitiya & 6 & 15 & 3 & 5 & & & & & & & & & & & & \\
\hline & Hakmana & 1 & 1 & - & - & & & & & & & & & & & & \\
\hline & Puhulwella & & & & & & & & & & & & & & & & \\
\hline \multirow[t]{5}{*}{ Hambantota } & Okewela & & & & & & & & & & & & & & & & \\
\hline & Weeraketiya & & & & & & & & & & & & & & & & \\
\hline & Walasmulla & & & & & & & & & & & & & & & & \\
\hline & Beliatta & 1 & 1 & - & - & & & & & & & & & & & & \\
\hline & Tangalle & 1 & 1 & - & - & & & & & & & & & & & & \\
\hline \multicolumn{2}{|c|}{ Total No. } & 16 & 29 & 6 & 12 & & & & & 5 & 7 & 3 & 5 & 1 & 1 & 1 & 1 \\
\hline
\end{tabular}

